\title{
Article
}

\section{An Electrochemical Sensor Based on Amino Magnetic Nanoparticle-Decorated Graphene for Detection of Cannabidiol}

\author{
Yi Zhang, Zongyi You, Chunsheng Hou, Liangliang Liu *(D) and Aiping Xiao *
}

check for

updates

Citation: Zhang, Y.; You, Z.; Hou, C.; Liu, L.; Xiao, A. An Electrochemical Sensor Based on Amino Magnetic

Nanoparticle-Decorated Graphene for Detection of Cannabidiol.

Nanomaterials 2021, 11, 2227. https:// doi.org/10.3390/nano11092227

Academic Editors: Nikolaos

V. Kantartzis and

Stamatios Amanatiadis

Received: 30 July 2021

Accepted: 25 August 2021

Published: 29 August 2021

Publisher's Note: MDPI stays neutral with regard to jurisdictional claims in published maps and institutional affiliations.

Copyright: (c) 2021 by the authors. Licensee MDPI, Basel, Switzerland. This article is an open access article distributed under the terms and conditions of the Creative Commons Attribution (CC BY) license (https:// creativecommons.org/licenses/by/ $4.0 /)$.
Institute of Bast Fiber Crops, Chinese Academy of Agricultural Sciences, Changsha 410205, China; zhang94721@gmail.com (Y.Z.); Xianyuxiaoyoujun@outlook.com (Z.Y.); houchensheng@caas.cn (C.H.)

* Correspondence: liuliangliang@caas.cn (L.L.); aipingxiao@yahoo.com (A.X.); Tel.: +86-731-88998525 (L.L.); +86-731-88998536 (A.X.)

\begin{abstract}
For detection of cannabidiol (CBD)—an important ingredient in Cannabis sativa L._-amino magnetic nanoparticle-decorated graphene $\left(\mathrm{Fe}_{3} \mathrm{O}_{4}-\mathrm{NH}_{2}-\mathrm{GN}\right)$ was prepared in the form of nanocomposites, and then modified on a glassy carbon electrode (GCE), resulting in a novel electrochemical sensor $\left(\mathrm{Fe}_{3} \mathrm{O}_{4}-\mathrm{NH}_{2}-\mathrm{GN} / \mathrm{GCE}\right)$. The applied $\mathrm{Fe}_{3} \mathrm{O}_{4}-\mathrm{NH}_{2}$ nanoparticles and GN exhibited typical structures and intended surface groups through characterizations via transmission electron microscopy (TEM), scanning electron microscopy (SEM), X-ray powder diffraction (XRD), vibrating sample magnetometer (VSM), and Raman spectroscopy. The $\mathrm{Fe}_{3} \mathrm{O}_{4}-\mathrm{NH}_{2}-\mathrm{GN} / \mathrm{GCE}$ showed the maximum electrochemical signal for CBD during the comparison of fabricated components via the cyclic voltammetry method, and was systematically investigated in the composition and treatment of components, $\mathrm{pH}$, scan rate, and quantitative analysis ability. Under optimal conditions, the $\mathrm{Fe}_{3} \mathrm{O}_{4}-\mathrm{NH}_{2}-\mathrm{GN} / \mathrm{GCE}$ exhibited a good detection limit $\left(0.04 \mu \mathrm{mol} \mathrm{L}^{-1}\right)$ with a linear range of $0.1 \mu \mathrm{mol} \mathrm{L}{ }^{-1}$ to $100 \mu \mathrm{mol} \mathrm{L}-1$ $\left(r^{2}=0.984\right)$. In the detection of CBD in the extract of $C$. sativa leaves, the results of the electrochemical method using the $\mathrm{Fe}_{3} \mathrm{O}_{4}-\mathrm{NH}_{2}$-GN/GCE were in good agreement with those of the HPLC method. Based on these findings, the proposed sensor could be further developed for the portable and rapid detection of natural active compounds in the food, agricultural, and pharmaceutical fields.
\end{abstract}

Keywords: cannabidiol; Cannabis sativa L.; electrochemical sensor; graphene; magnetic nanoparticles

\section{Introduction}

Cannabis sativa L. (C. sativa) is an annual dioecious herb belonging to the Cannabinaceae family, which is cultivated worldwide, and was one of the original crops in China [1]. C. sativa can be simply divided into industrial hemp and marijuana-generally distinguished by the content of $\Delta^{9}$-Tetrahydrocannabinol $\left(\Delta^{9}-\mathrm{THC}\right)$ in the plant; it is considered to be industrial hemp when the content of $\Delta^{9}$-THC is lower than $0.3 \%(w / w)$, and otherwise is referred to as marijuana. Based on the existing legal requirements in China, the cultivation of marijuana is banned; all varieties of $C$. sativa planted in China belong to the industrial hemp category [2]. In recent years, the medicinal usage of cannabidiol (CBD) has received unprecedented attention in the pharmaceutical and cosmetics industries. Accordingly, as the natural extraction source of CBD, C. sativa has ushered in a new round of development [3]. As an isomeride of $\Delta^{9}-\mathrm{THC}, \mathrm{CBD}$ is non-psychoactive and exhibits good pharmacological effects in treating chronic pain, anxiety, inflammation, depression, and many other symptoms [4,5]. Today, the quantitative analysis methods of cannabinoids-including CBD-are mainly chromatographic methods, such as high-performance liquid chromatography (HPLC), gas chromatography (GC), and mass spectrometry [6-8].

As a kind of ultrasensitive detection method, electrochemical sensors or biosensors are mainly reported for the detection of $\Delta^{9}-\mathrm{THC}$, since $\Delta^{9}-\mathrm{THC}$ is a typical psychoactive drug and is strictly regulated [9]. However, electrochemical sensors developed for the detection of CBD are rare. Since the interest in (and market for) CBD and related products 
are growing, the detection of CBD has also become more important [10]. A convenient and rapid strategy for the detection of CBD could meet many needs in various scenarios outside of the laboratory. Through customization in the size and composition of sensors, in combination with the design of a small and portable workstation, a preliminary and rapid detection of CBD in plants could be completed in the field, which could save a lot of work for farmers or researchers [11]. Therefore, the effort to develop electrochemical sensors for CBD using novel nanomaterials is worthwhile.

As a typical two-dimensional nanomaterial, graphene (GN) has displayed many properties, including large specific surface area, high chemical stability, and excellent electrochemical properties [12]. It is widely used to modify electrodes in order to achieve better results in applications of supercapacitors, potassium-ion batteries, and detectors for biomarkers, metabolites, viruses, etc. [13-16]. The beneficial effects of modification of electrochemical sensors have been proven, including route simplicity, high efficiency, good performance, and low cost [17]. Magnetic nanoparticles such as iron oxide also show characteristics such as low toxicity, ease of functionalization, high adsorption ability, and magnetic responsivity [18]. The introduction of magnetic nanoparticles in electrochemical sensors could facilitate of electron transfer and signal amplification. The combination of GN and magnetic nanoparticles, resulting in $\mathrm{Fe}_{3} \mathrm{O}_{4} / \mathrm{GN}$ nanocomposites, has been utilized in the construction of various electrochemical sensors [19]. The $\mathrm{Fe}_{3} \mathrm{O}_{4} / \mathrm{GN}$ nanocomposites have been applied with satisfactory performance in the electrochemical detection of arsenic ions, lobetyolin, dopamine, glucose, prostate-specific antigen, hepatitis C virus, etc. [20-25].

In this study, many materials were tested for the modification of electrodes in order to obtain higher signals in the electrochemical detection of CBD. Amino-group-modified $\mathrm{Fe}_{3} \mathrm{O}_{4}$ nanoparticles $\left(\mathrm{Fe}_{3} \mathrm{O}_{4}-\mathrm{NH}_{2}\right)$ were finally confirmed for the modification of a glassy carbon electrode (GCE) together with GN in the form of nanocomposites. After the characterizations of the materials, $\mathrm{GN}$ and $\mathrm{Fe}_{3} \mathrm{O}_{4}-\mathrm{NH}_{2}$ were mixed as nanocomposites and modified on the GCE $\left(\mathrm{Fe}_{3} \mathrm{O}_{4}-\mathrm{NH}_{2}-\mathrm{GN} / \mathrm{GCE}\right)$ to develop a novel electrochemical sensor for the highly selective and sensitive detection of CBD (Figure 1). The composition and fabrication sequences of the modifiers were investigated and optimized. Under the optimal fabrication and analytical conditions, the proposed $\mathrm{Fe}_{3} \mathrm{O}_{4}-\mathrm{NH}_{2}-\mathrm{GN} / \mathrm{GCE}$ demonstrated enhanced electrochemical signals, good linearity, and satisfactory anti-interference ability for CBD. The CBD content of $C$. sativa leaf extract was detected using the proposed $\mathrm{Fe}_{3} \mathrm{O}_{4}{ }^{-}$ $\mathrm{NH}_{2}-\mathrm{GN} / \mathrm{GCE}$, and the results were compared with those of the conventional HPLC method. Hence, it can be expected that the $\mathrm{Fe}_{3} \mathrm{O}_{4}-\mathrm{NH}_{2}-\mathrm{GN} / \mathrm{GCE}$ has extensive potential applications in the detection of CBD and other natural ingredients.

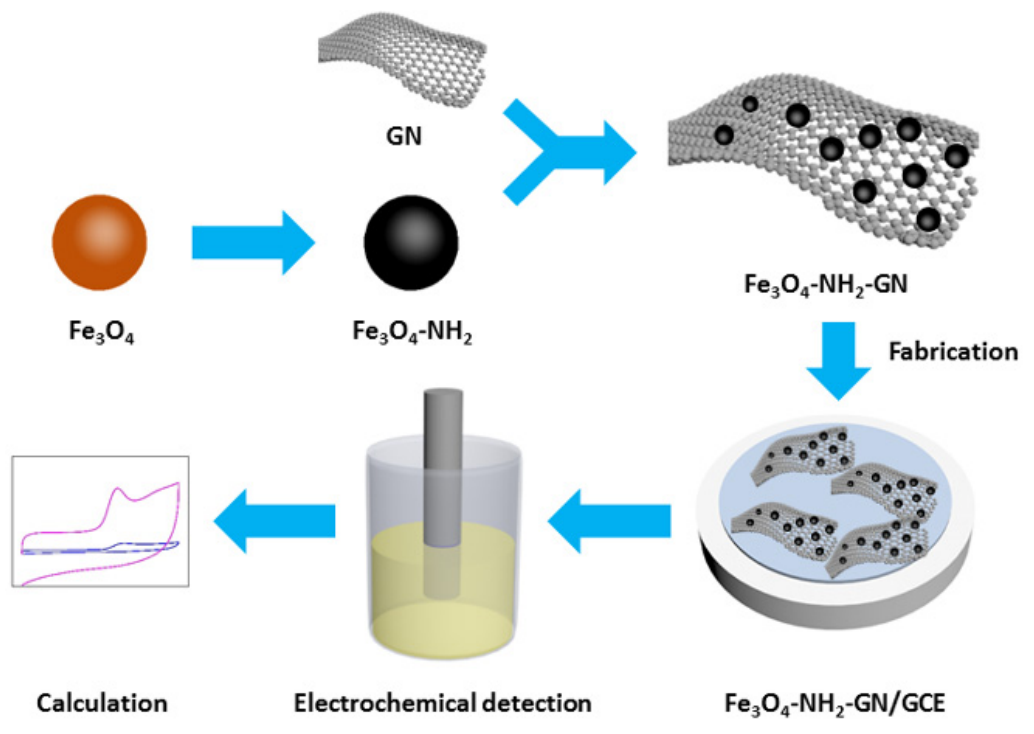

Figure 1. Diagram of $\mathrm{Fe}_{3} \mathrm{O}_{4}-\mathrm{NH}_{2}-\mathrm{GN} / \mathrm{GCE}$ and electrochemical detection of CBD. 


\section{Materials and Methods}

\subsection{Reagents and Apparatus}

Detailed information about the reagents and instrumentations can be found in the Supplementary Material.

\subsection{Preparation of $\mathrm{Fe}_{3} \mathrm{O}_{4}-\mathrm{NH}_{2}$ Nanoparticles}

$\mathrm{Fe}_{3} \mathrm{O}_{4}$ nanoparticles were prepared according to our previous report [26]. Typically, $1.35 \mathrm{~g}$ of ferric chloride, $3.60 \mathrm{~g}$ of sodium acetate, and $1.00 \mathrm{~g}$ of PEG 6000 were mixed in $50 \mathrm{~mL}$ of ethylene glycol. The mixture was stirred under ultrasonication for $30 \mathrm{~min}$ and poured into a Teflon-lined stainless steel autoclave $(100 \mathrm{~mL})$. The autoclave was put into a drying oven at $180^{\circ} \mathrm{C}$ for $6 \mathrm{~h}$. After reaction, the black products were poured out and washed with water and ethanol three times each.

The obtained $\mathrm{Fe}_{3} \mathrm{O}_{4}$ nanoparticles were then dispersed in $250 \mathrm{~mL}$ of ethanol and ultrasonicated for $30 \mathrm{~min}$ [27]. After that, the materials were poured into a round-bottomed flask, and $2 \mathrm{~mL}$ of 3-aminopropyltriethoxysilane was dripped slowly into the $\mathrm{Fe}_{3} \mathrm{O}_{4}$ nanoparticle dispersion under mechanical agitation. The reaction was performed at room temperature for $6 \mathrm{~h}$. Finally, the $\mathrm{Fe}_{3} \mathrm{O}_{4}-\mathrm{NH}_{2}$ nanoparticles were washed with ethanol three times and stored in ethanol at $4{ }^{\circ} \mathrm{C}$.

\subsection{Fabrication of the $\mathrm{Fe}_{3} \mathrm{O}_{4}-\mathrm{NH}_{2}-\mathrm{GN} / \mathrm{GCE}$}

Before modification, the GCE was polished using alumina powders $(0.05 \mu \mathrm{m})$ and cleaned via ultrasonication for $10 \mathrm{~min}$. The surface of the GCE was dried with nitrogen gas and stored for further use. Next, $12.0 \mathrm{mg}$ of $\mathrm{Fe}_{3} \mathrm{O}_{4}-\mathrm{NH}_{2}$ nanoparticles and $12.0 \mathrm{mg}$ of GN were mixed in $2.0 \mathrm{~mL}$ of water and ultrasonicated for $10 \mathrm{~min}$ to form a homogeneous solution, which was marked as $\mathrm{Fe}_{3} \mathrm{O}_{4}-\mathrm{NH}_{2}-\mathrm{GN}$ nanocomposites. Then, $10 \mu \mathrm{L}$ of the $\mathrm{Fe}_{3} \mathrm{O}_{4}$ $\mathrm{NH}_{2}$-GN suspension $(6.0 \mathrm{mg} / \mathrm{mL}$ in water) was carefully dropped on the surface of GCE and air-dried to form an active layer on the surface of the electrode. The modified electrode was referred to as $\mathrm{Fe}_{3} \mathrm{O}_{4}-\mathrm{NH}_{2}$-GN/GCE.

For comparison, $10 \mu \mathrm{L}$ of $\mathrm{Fe}_{3} \mathrm{O}_{4}-\mathrm{NH}_{2}$ nanoparticles and $\mathrm{GN}(6.0 \mathrm{mg} / \mathrm{mL}$ in water) were fabricated on the GCE in the same procedures and conditions, which were designated as $\mathrm{Fe}_{3} \mathrm{O}_{4}-\mathrm{NH}_{2} / \mathrm{GCE}$ and GN/GCE, respectively. For confirmation of the fabrication sequence, three kinds of sequences were compared. $\mathrm{Fe}_{3} \mathrm{O}_{4}-\mathrm{NH}_{2}$ nanoparticles were firstly dropped on the surface of GCE; GN was then dropped on the surface when the nanomaterials were dried, the result of which was designated as GN/Fe $3 \mathrm{O}_{4}-\mathrm{NH}_{2} / \mathrm{GCE}$. GN was firstly modified on the bare GCE, and then $\mathrm{Fe}_{3} \mathrm{O}_{4}-\mathrm{NH}_{2}$ nanoparticles were modified, which was designated as $\mathrm{Fe}_{3} \mathrm{O}_{4}-\mathrm{NH}_{2} / \mathrm{GN} / \mathrm{GCE}$. These two electrodes were compared with $\mathrm{Fe}_{3} \mathrm{O}_{4}-\mathrm{NH}_{2}-\mathrm{GN} / \mathrm{GCE}$ for their electrochemical response under the same conditions.

\subsection{Preparation of Real Sample}

Dry C. sativa leaves were ground, passed through a 40-mesh sieve, and placed in an oven at $105{ }^{\circ} \mathrm{C}$ for $10 \mathrm{~h}$. After these treatments, $0.5 \mathrm{~g}$ of $\mathrm{C}$. sativa leaves was immersed in $50 \mathrm{~mL}$ of anhydrous methanol solution. The mixture was extracted for $20 \mathrm{~min}$ using an ultrasonic extractor at a power of $200 \mathrm{~W}$ (KQ5200DV, Kunshan Ultrasonic Instrument Co., Ltd., Kunshan, China). After extraction, the mixture was centrifuged at $4000 \mathrm{r} / \mathrm{min}$ for 5 min (TD5, Yingtai Instrument Co., Ltd., Changsha, China). Next, $2 \mathrm{~mL}$ of the upper transparent solution was diluted to $20 \mathrm{~mL}$ with phosphate buffer solution (PBs, $10 \mathrm{mmol} \mathrm{L}^{-1}$, $\mathrm{pH}$ 5.0) and filtered with $0.45 \mu \mathrm{m}$ filter before analyses via HPLC and using the proposed sensor.

\subsection{Determination of CBD by HPLC}

For comparison of the detection results, the HPLC method was applied in the detection of samples as well. An isocratic elution program consisting of $0.1 \%$ acetic acid and $75 \%$ acetonitrile was applied for $30 \mathrm{~min}$ at $25^{\circ} \mathrm{C}$. The flow rate was set to $0.8 \mathrm{~mL} / \mathrm{min}$. The chromatogram was observed at $220 \mathrm{~nm}$. The injection volume of the sample was $10 \mu \mathrm{L}$. The 
CBD content in the C. sativa leaf extract was calculated using the standard curve obtained by the measurement standards.

\subsection{Electrochemical Measurements}

The electrochemical measurements were performed using the three-electrode system in CBD solution, using PBs (10 $\mathrm{mmol} \mathrm{L}^{-1}, \mathrm{pH} 5.0$, containing 10\% methanol) as a solvent and supporting electrolyte. Cyclic voltammetry (CV) was used for the measurement, with a scan rate of $0.05 \mathrm{~V} \mathrm{~s}^{-1}$ and a potential range from $0 \mathrm{~V}$ to $0.8 \mathrm{~V}$. Electrochemical impedance spectroscopy (EIS) was applied to characterize the sensor conductivity in the solution containing $5.0 \mathrm{mmol} \mathrm{L}^{-1}$ of $\mathrm{K}_{3}\left[\mathrm{Fe}(\mathrm{CN})_{6}\right] / \mathrm{K}_{4}\left[\mathrm{Fe}(\mathrm{CN})_{6}\right]$ and $0.1 \mathrm{~mol} \mathrm{~L}^{-1}$ of potassium chloride. The amplitude was $0.005 \mathrm{~V}$ with a frequency range of 0.1 to $10^{5} \mathrm{~Hz}$. All experiments were carried out in three duplicates at $25 \pm 2{ }^{\circ} \mathrm{C}$.

\section{Results and Discussion}

\subsection{Characterizations of Nanomaterials}

\subsubsection{TEM and SEM}

The morphologies of $\mathrm{Fe}_{3} \mathrm{O}_{4}$ nanoparticles, $\mathrm{GN}$, and $\mathrm{Fe}_{3} \mathrm{O}_{4}-\mathrm{NH}_{2}-\mathrm{GN}$ were investigated via TEM (Figure 2). The round sphere of $\mathrm{Fe}_{3} \mathrm{O}_{4}$ nanoparticles, as well as the silk-like and wrinkled structures of GN, could be easily observed in the corresponding images (Figure 2a,b) [28]. The $\mathrm{Fe}_{3} \mathrm{O}_{4}$ nanoparticles showed sizes of about $430 \mathrm{~nm}$, with good dispersion. After mixing, the $\mathrm{Fe}_{3} \mathrm{O}_{4}-\mathrm{NH}_{2}-\mathrm{GN}$ nanocomposites retained the characteristics of $\mathrm{Fe}_{3} \mathrm{O}_{4}$ nanoparticles and GN. It can be seen in the TEM image that $\mathrm{Fe}_{3} \mathrm{O}_{4}$ nanoparticles were dispersed on the GN sheets (Figure 2c) [29].
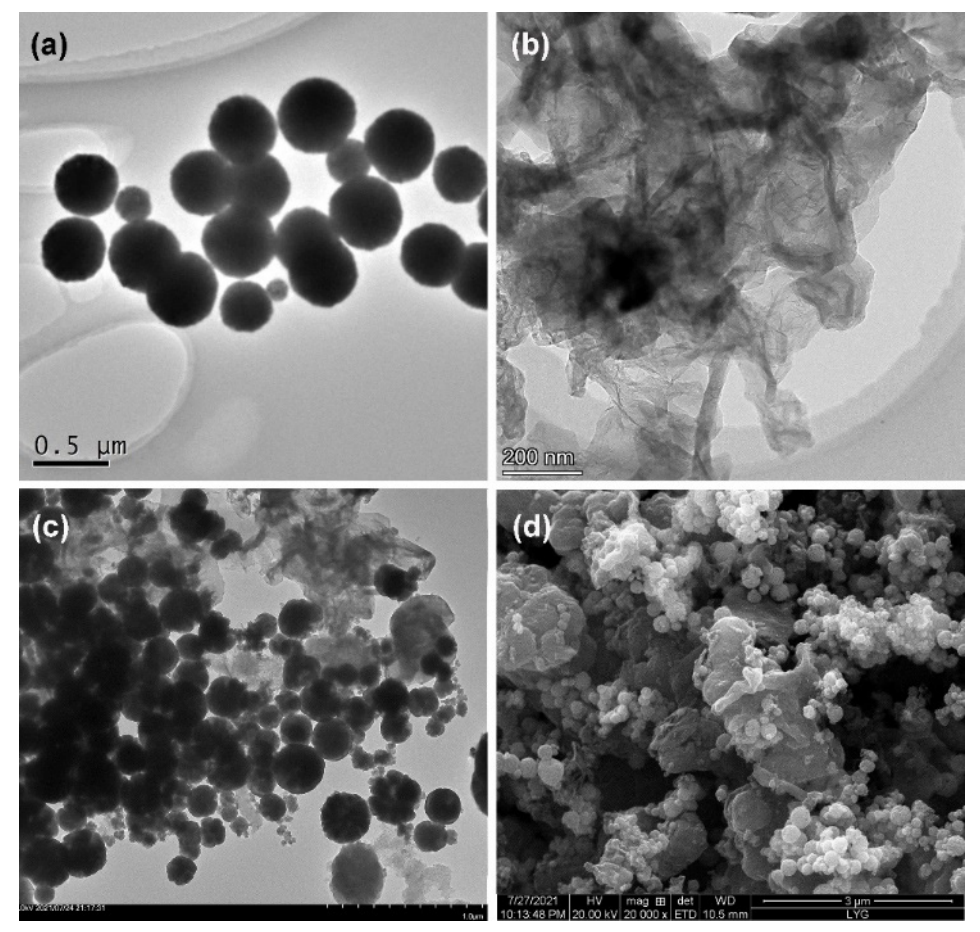

Figure 2. TEM images of (a) $\mathrm{Fe}_{3} \mathrm{O}_{4}$, (b) GN, and (c) $\mathrm{Fe}_{3} \mathrm{O}_{4}-\mathrm{NH}_{2}-\mathrm{GN}$. (d) SEM image of $\mathrm{Fe}_{3} \mathrm{O}_{4}-\mathrm{NH}_{2}-\mathrm{GN}$.

An SEM image of the $\mathrm{Fe}_{3} \mathrm{O}_{4}-\mathrm{NH}_{2}-\mathrm{GN}$ nanocomposites on the electrode surface was also provided in order to confirm the morphology and structure (Figure 2d), and showed the modified surface of the electrode. Though there was a kind of agglomeration in the nanocomposites, the existence of $\mathrm{Fe}_{3} \mathrm{O}_{4}$ nanoparticles (round spheres) on the GN could be confirmed. The irregular surface of the modified electrode might be one of the reasons for the improved electrochemical response. 


\subsubsection{XRD}

The XRD patterns of $\mathrm{Fe}_{3} \mathrm{O}_{4}$ nanoparticles, $\mathrm{GN}$, and $\mathrm{Fe}_{3} \mathrm{O}_{4}-\mathrm{NH}_{2}-\mathrm{GN}$ were analyzed, and are shown in Figure 3a. The pattern of $\mathrm{Fe}_{3} \mathrm{O}_{4}$ nanoparticles exhibited typical peaks at $30.3^{\circ}, 35.7^{\circ}, 43.6^{\circ}, 57.4^{\circ}$, and 62.9 , which were attributed to the indices (220), (311), (400), (511), and (440) of the $\mathrm{Fe}_{3} \mathrm{O}_{4}$ crystal, respectively [30]. Meanwhile, in the pattern of $\mathrm{Fe}_{3} \mathrm{O}_{4}-\mathrm{NH}_{2}-\mathrm{GN}$, the related peaks became much weaker, which might be a result of the coating of GN and the modification of the amino groups [26]. Additionally, another peak at $\sim 26^{\circ}$ could be observed, belonging to the characteristic reflection of the existence of GN [31]. The XRD results confirmed the existence of $\mathrm{Fe}_{3} \mathrm{O}_{4}$ nanoparticles and GN in the $\mathrm{Fe}_{3} \mathrm{O}_{4}-\mathrm{NH}_{2}-\mathrm{GN}$ nanocomposites.
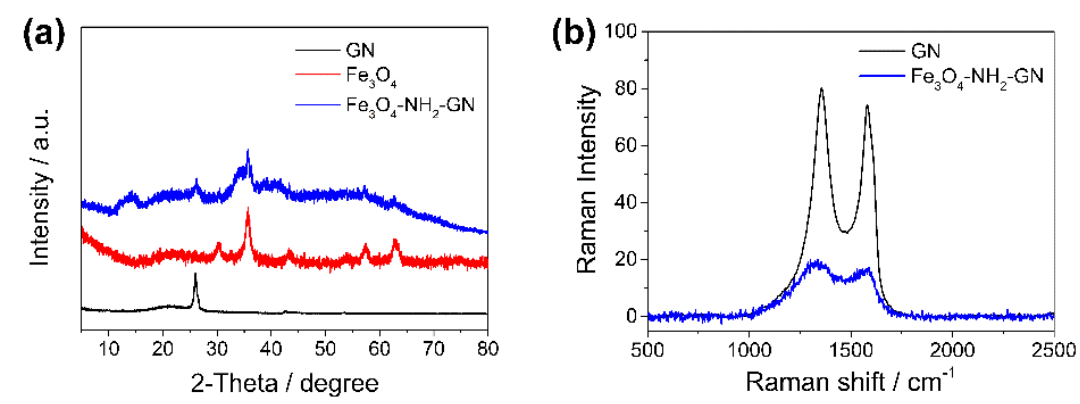

Figure 3. (a) $\mathrm{XRD}$ patterns of $\mathrm{GN}, \mathrm{Fe}_{3} \mathrm{O}_{4}$, and $\mathrm{Fe}_{3} \mathrm{O}_{4}-\mathrm{NH}_{2}-\mathrm{GN}$. (b) Raman spectra of $\mathrm{GN}$ and $\mathrm{Fe}_{3} \mathrm{O}_{4}-\mathrm{NH}_{2}-\mathrm{GN}$.

\subsubsection{Raman}

Figure $3 \mathrm{~b}$ illustrates the Raman spectra of the $\mathrm{GN}$ and $\mathrm{Fe}_{3} \mathrm{O}_{4}-\mathrm{NH}_{2}-\mathrm{GN}$ nanocomposites. Both GN and $\mathrm{Fe}_{3} \mathrm{O}_{4}-\mathrm{NH}_{2}-\mathrm{GN}$ showed two peaks at around $1350 \mathrm{~cm}^{-1}$ and $1570 \mathrm{~cm}^{-1}$, which were designated as $\mathrm{D}$ band and $\mathrm{G}$ band; they represented the disordered sp3 carbon structure ( $D$ band) and the sp2 ordered crystalline structure (G band) of GN [32]. After the combination of the two nanomaterials, the intensities of the peaks reduced significantly, which might be a result of the introduction of $\mathrm{Fe}_{3} \mathrm{O}_{4}-\mathrm{NH}_{2}$ nanoparticles. However, the intensity ratio of the $\mathrm{D}$ to $\mathrm{G}$ peaks was maintained, showing that the structure of GN was not affected.

\subsection{Electrochemical Characteristics}

The electrochemical behavior of various modified electrodes in $100 \mu \mathrm{mol} \mathrm{L}-1$ of CBD were compared via the CV method. As shown in Figure 4a, the electrochemical response of CBD on bare GCE was only $0.728 \mu \mathrm{A}$ (black line). After the respective modifications with $\mathrm{Fe}_{3} \mathrm{O}_{4}$ nanoparticles and GN to the GCE, small oxidation peaks at around $0.5 \mathrm{~V}$ could be observed on the $\mathrm{Fe}_{3} \mathrm{O}_{4}$ /GCE (blue line) and the GN/GCE (red line), which might be due to the electron transfer properties and the good conductivity of $\mathrm{Fe}_{3} \mathrm{O}_{4}$ nanomaterials and GN [33]. When $\mathrm{Fe}_{3} \mathrm{O}_{4}$-GN suspensions were used to modify the GCE, resulting in the $\mathrm{Fe}_{3} \mathrm{O}_{4}$-GN/GCE, an apparent increase in peak current could be observed $(5.659 \mu \mathrm{A}$, green line). The advantages of $\mathrm{GN}$ and $\mathrm{Fe}_{3} \mathrm{O}_{4}$ nanoparticles were combined and enhanced. Moreover, when the $\mathrm{Fe}_{3} \mathrm{O}_{4}$ nanoparticles were functionalized by amino groups, the resulting modified electrode $\left(\mathrm{Fe}_{3} \mathrm{O}_{4}-\mathrm{NH}_{2}-\mathrm{GN} / \mathrm{GCE}\right)$ showed the highest response among these electrodes $(8.978 \mu \mathrm{A}$, Pink line). In order to confirm the effect of amino groups on $\mathrm{Fe}_{3} \mathrm{O}_{4}$ nanoparticles, $\mathrm{Fe}_{3} \mathrm{O}_{4}$-nanoparticle- and $\mathrm{Fe}_{3} \mathrm{O}_{4}-\mathrm{NH}_{2}$-nanoparticle-modified electrodes $\left(\mathrm{Fe}_{3} \mathrm{O}_{4} / \mathrm{GCE}\right.$ and $\left.\mathrm{Fe}_{3} \mathrm{O}_{4}-\mathrm{NH}_{2} / \mathrm{GCE}\right)$ were compared. As a result, the peak current of $\mathrm{Fe}_{3} \mathrm{O}_{4}-\mathrm{NH}_{2} / \mathrm{GCE}$ was slightly higher than that of $\mathrm{Fe}_{3} \mathrm{O}_{4} / \mathrm{GCE}$ (1.366 to 1.08, not shown). A possible reason for this increase might be that the amino groups on the surface could attract more target molecules. As far as we know, there has been no previous report regarding the electrochemical oxidation mechanism of $\mathrm{CBD}$. By referring to reported works on the oxidation of $\Delta^{9}$-THC, the oxidation process of CBD could be assumed to be a phenol-type oxidation mechanism [34,35]. 

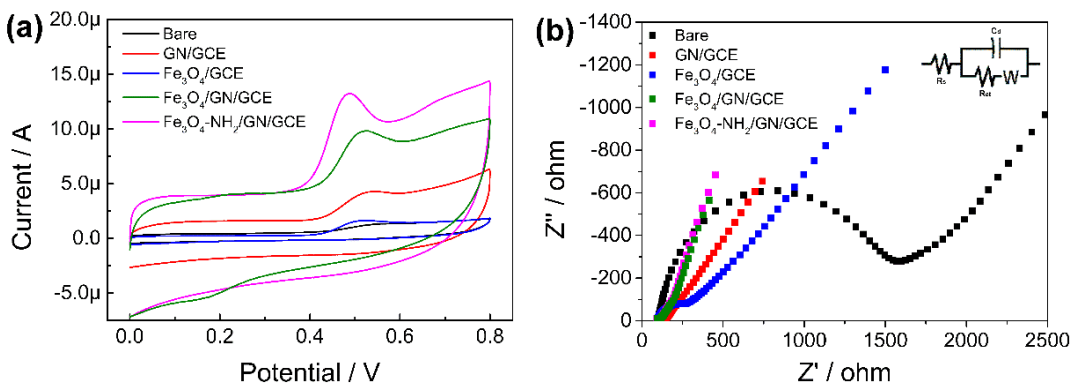

Figure 4. (a) CV curves of CBD on bare GCE, GN/GCE, $\mathrm{Fe}_{3} \mathrm{O}_{4} / \mathrm{GCE}, \mathrm{Fe}_{3} \mathrm{O}_{4}$-GN/GCE, and $\mathrm{Fe}_{3} \mathrm{O}_{4}$ $\mathrm{NH}_{2}$-GN/GCE. CV method: $100 \mu \mathrm{mol} \mathrm{L}{ }^{-1}$ of CBD in $10 \mathrm{mmol} \mathrm{L}^{-1}$ of PBs (pH 5.0, containing $10 \%$ methanol). Potential range of $0-0.8 \mathrm{~V}$. Scan rate of $0.05 \mathrm{~V} \mathrm{~s}^{-1}$. (b) Nyquist plots of bare GCE, GN/GCE, $\mathrm{Fe}_{3} \mathrm{O}_{4} / \mathrm{GCE}, \mathrm{Fe}_{3} \mathrm{O}_{4}-\mathrm{GN} / \mathrm{GCE}$, and $\mathrm{Fe}_{3} \mathrm{O}_{4}-\mathrm{NH}_{2}-\mathrm{GN} / \mathrm{GCE}$ in $5.0 \mathrm{mmol} \mathrm{L}{ }^{-1}$ of $\mathrm{K}_{3}\left[\mathrm{Fe}(\mathrm{CN})_{6}\right] / \mathrm{K}_{4}\left[\mathrm{Fe}(\mathrm{CN})_{6}\right]$ and $0.1 \mathrm{~mol} \mathrm{~L}^{-1}$ of potassium chloride. The amplitude is $0.005 \mathrm{~V}$, with a frequency range of 0.1 to $10^{5} \mathrm{~Hz}$.

In order to optimize the effects of the modifiers, the fabrication sequence of modified sensors was investigated. Through the comparison of $\mathrm{GN} / \mathrm{Fe}_{3} \mathrm{O}_{4}-\mathrm{NH}_{2} / \mathrm{GCE}, \mathrm{Fe}_{3} \mathrm{O}_{4}$ $\mathrm{NH}_{2} / \mathrm{GN} / \mathrm{GCE}$, and $\mathrm{Fe}_{3} \mathrm{O}_{4}-\mathrm{NH}_{2}-\mathrm{GN} / \mathrm{GCE}$, the peak currents of each sensor were obtained, as shown in Table 1. Apparently, the $\mathrm{Fe}_{3} \mathrm{O}_{4}-\mathrm{NH}_{2}-\mathrm{GN} / \mathrm{GCE}$ showed the best response among these sensors, meaning that the modifiers should first be mixed, and then dropped directly on the surface of the electrode. Based on this finding, different preparation methods of $\mathrm{Fe}_{3} \mathrm{O}_{4}-\mathrm{NH}_{2}-\mathrm{GN}$ suspensions were tried (see the ESM). Three kinds of $\mathrm{Fe}_{3} \mathrm{O}_{4}-\mathrm{NH}_{2}-\mathrm{GN}$ nanocomposites were compared, and their corresponding peak currents are also shown in Table 1. Although the $\mathrm{Fe}_{3} \mathrm{O}_{4}$ nanoparticles were directly prepared in the presence of GN via ultrasonication and solvothermal methods, the electrochemical properties obtained were not as good as via the physical mix method. Hence, the $\mathrm{Fe}_{3} \mathrm{O}_{4}-\mathrm{NH}_{2}-\mathrm{GN}$ suspension was confirmed as the optimal material in this research.

Table 1. The $I_{p}$ in different fabrication sequences and process methods of $\mathrm{Fe}_{3} \mathrm{O}_{4}-\mathrm{NH}_{2}-\mathrm{GN}$ in modified electrodes.

\begin{tabular}{cccc}
\hline Fabrication Sequence & $\boldsymbol{I}_{\boldsymbol{p}}(\boldsymbol{\mu A} \mathbf{A})$ & Process Method & $\boldsymbol{I}_{\boldsymbol{p}}(\boldsymbol{\mu A})$ \\
\hline $\mathrm{GN} / \mathrm{Fe}_{3} \mathrm{O}_{4}-\mathrm{NH}_{2} / \mathrm{GCE}$ & 1.808 & Ultrasonication & 3.352 \\
$\mathrm{Fe}_{3} \mathrm{O}_{4}-\mathrm{NH}_{2} / \mathrm{GN} / \mathrm{GCE}$ & 3.388 & Solvothermal & 4.232 \\
$\mathrm{Fe}_{3} \mathrm{O}_{4}-\mathrm{NH}_{2}-\mathrm{GN} / \mathrm{GCE}$ & 5.327 & Mix & 5.550 \\
\hline
\end{tabular}

The Nyquist plots from the EIS test reflect the conductivity of the electrodes (Figure 4b). The inset of Figure $4 \mathrm{~b}$ shows a general equivalent circuit containing the solution resistance $\left(R_{S}\right)$, the electron transfer resistance $\left(R_{e t}\right)$, the Warburg element $(W)$, and the charge of the constant phase element $\left(C_{d}\right)$ [36]. The value of $R_{\text {et }}$ was calculated by fitting the experimental data to the model circuit. As shown in Figure $4 b$, the Nyquist plot of bare GCE showed a semicircle, with an $R_{\text {et }}$ of $1287 \Omega$. When the GCE was modified with $\mathrm{Fe}_{3} \mathrm{O}_{4}$ nanoparticles and GN, the $\mathrm{R}_{\text {et }}$ of $\mathrm{Fe}_{3} \mathrm{O}_{4} / \mathrm{GCE}$ and GN/GCE reduced to $141.4 \Omega$ and $28.61 \Omega$, respectively. Finally, the $\mathrm{R}_{\text {et }}$ of $\mathrm{Fe}_{3} \mathrm{O}_{4}-\mathrm{NH}_{2}-\mathrm{GN} / \mathrm{GCE}$ was only $13.73 \Omega$, which was similar to that of $\mathrm{Fe}_{3} \mathrm{O}_{4}-\mathrm{GN} / \mathrm{GCE}(16.19 \Omega)$. The decreases in resistance could be attributed to the outstanding electric conductivity of GN and magnetic nanoparticles [37]. Consequently, the $\mathrm{Fe}_{3} \mathrm{O}_{4}-\mathrm{NH}_{2}-\mathrm{GN} / \mathrm{GCE}$ was confirmed as the optimal modified sensor, by reason of its optimal response and conductivity in electrochemical detection.

\subsection{Optimization of Electrochemical Conditions}

\subsubsection{Effect of Composition of $\mathrm{Fe}_{3} \mathrm{O}_{4}-\mathrm{NH}_{2}-\mathrm{GN}$}

In order to obtain the optimal mixture composition, the ratios of $\mathrm{GN}$ and $\mathrm{Fe}_{3} \mathrm{O}_{4}-\mathrm{NH}_{2}$ nanoparticles $(1: 0.5,1: 1,1: 1.25,1: 1.5,1: 2.0$ and 1:2.5, w:w) were investigated, and are shown 
in Figure 5a. The concentration of GN was set at $2.0 \mathrm{mg} \mathrm{mL}^{-1}$, and the concentrations of $\mathrm{Fe}_{3} \mathrm{O}_{4}-\mathrm{NH}_{2}$ nanoparticles were verified according to the ratios. These illustrated results suggested that the electrochemical signals of CBD were the highest when the ratio was 1:1. When the ratio of $\mathrm{Fe}_{3} \mathrm{O}_{4}-\mathrm{NH}_{2}$ nanoparticles was higher than 1.0, the response gradually became weaker. Therefore, the material ratio of $\mathrm{GN}$ and $\mathrm{Fe}_{3} \mathrm{O}_{4}-\mathrm{NH}_{2}$ nanoparticles was set to $1: 1$ as the optimal composition for the fabrication of the electrode.
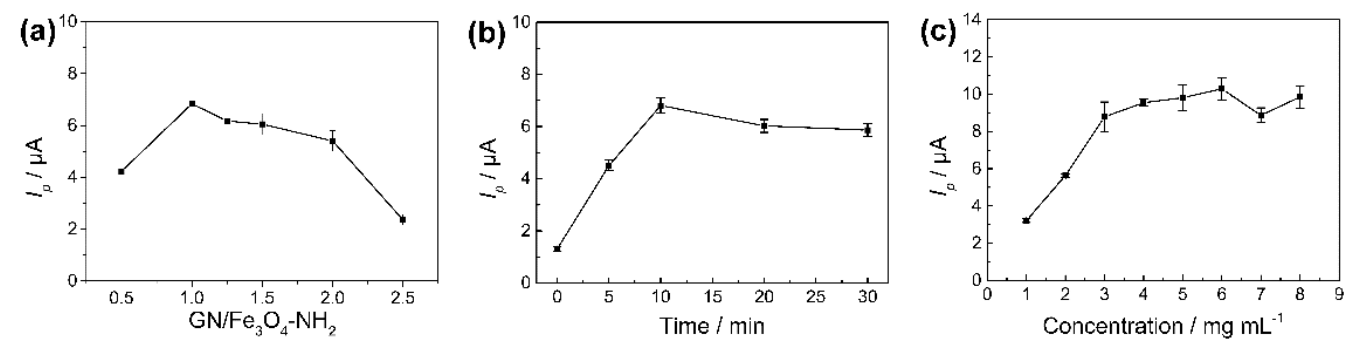

Figure 5. (a) Effect of compositions of $\mathrm{Fe}_{3} \mathrm{O}_{4}-\mathrm{NH}_{2}-\mathrm{GN}$ on $I_{p}$ in CV. (b) Effect of ultrasonication time of $\mathrm{Fe}_{3} \mathrm{O}_{4}-\mathrm{NH}_{2}-\mathrm{GN}$ on $I_{p}$ in CV. (c) Effect of modification volumes on peak current in CV. CV method: $100 \mu \mathrm{mol} \mathrm{L}{ }^{-1}$ of CBD in $10 \mathrm{mmol} \mathrm{L}^{-1}$ of PBs (pH 5.0, containing $10 \%$ methanol). Potential range of $0-0.8 \mathrm{~V}$. Scan rate of $0.05 \mathrm{~V} \mathrm{~s}^{-1}$.

\subsubsection{Effect of Ultrasonication Time of $\mathrm{Fe}_{3} \mathrm{O}_{4}-\mathrm{NH}_{2}-\mathrm{GN}$}

To obtain a stable dispersion, various ultrasonication times of the $\mathrm{Fe}_{3} \mathrm{O}_{4}-\mathrm{NH}_{2}-\mathrm{GN}$ suspension were tested, from $1 \mathrm{~min}$ to $30 \mathrm{~min}(1,5,10,20$, and $30 \mathrm{~min})$. Then, the materials were used for the fabrication of electrodes. The changes in peak currents using the corresponding modified electrodes are plotted in Figure 5b. It can be seen that the electrochemical response was the highest when the material was treated for $10 \mathrm{~min}$. However, longer ultrasonication time did not make the response better. Hence, the ultrasonication time of $\mathrm{Fe}_{3} \mathrm{O}_{4}-\mathrm{NH}_{2}-\mathrm{GN}$ suspension was confirmed at $10 \mathrm{~min}$.

\subsubsection{Effect of Concentration of $\mathrm{Fe}_{3} \mathrm{O}_{4}-\mathrm{NH}_{2}-\mathrm{GN}$}

The effect of concentration of $\mathrm{Fe}_{3} \mathrm{O}_{4}-\mathrm{NH}_{2}-\mathrm{GN}$ suspension was measured from $1.0 \mathrm{mg} \mathrm{mL}^{-1}$ to $8.0 \mathrm{mg} \mathrm{mL}^{-1}$, and the modification volume was fixed at $10.0 \mu \mathrm{L}$. As the previous experiment indicated, the ratio of $\mathrm{GN}$ and $\mathrm{Fe}_{3} \mathrm{O}_{4}-\mathrm{NH}_{2}$ nanoparticles was set at $1: 1(w: w)$. It can be seen in Figure $5 c$ that the peak current increased as the concentration increased from $1.0 \mathrm{mg} \mathrm{mL}^{-1}$ to $6.0 \mathrm{mg} \mathrm{mL}^{-1}$. However, when the concentrations were more than $6.0 \mathrm{mg} \mathrm{mL}^{-1}$, this trend stopped, and the response began to gradually drop, which was similar to the results of a previous report [38]. Then, the concentration of $\mathrm{Fe}_{3} \mathrm{O}_{4}-\mathrm{NH}_{2}-\mathrm{GN}$ suspension was optimized as $6.0 \mathrm{mg} \mathrm{mL}^{-1}$.

\subsubsection{Effect of $\mathrm{pH}$}

The electrochemical detection using various $\mathrm{pH}$ values of the electrolyte $(4.0,5.0,6.0$, 7.0, 8.0, and 9.0) containing CBD as samples was performed with the $\mathrm{Fe}_{3} \mathrm{O}_{4}-\mathrm{NH}_{2}-\mathrm{GN} / \mathrm{GCE}$, using the CV method. The trend is shown in Figure $6 \mathrm{a}$, and the peak current of CBD was the highest when the $\mathrm{pH}$ of the electrolyte was 5.0. There was a downward trend when the $\mathrm{pH}$ of the electrolyte became higher than 5.0, which is consistent with Zanardi's research [39]. Thus, 5.0 was adopted as the optimal electrolyte $\mathrm{pH}$ value during the tests.

Moreover, it could be observed that there was a linear shit of the peak potential (Ep) to lower positive values as the $\mathrm{pH}$ increased. The linear equation between Ep and $\mathrm{pH}$ was expressed as Ep $=-0.053 \mathrm{pH}+0.863\left(r^{2}=0.984\right)$ (Figure $\left.6 \mathrm{~b}\right)$. The slope of the equation was $\sim-0.053 \mathrm{~V} \mathrm{pH}^{-1}$, similar to the theoretical Nernstian slope of $0.059 \mathrm{~V} \mathrm{pH}^{-1}$. This parameter corresponded to an oxidation mechanism that included the exchange of an equal number of protons and electrons in the reaction [40]. 

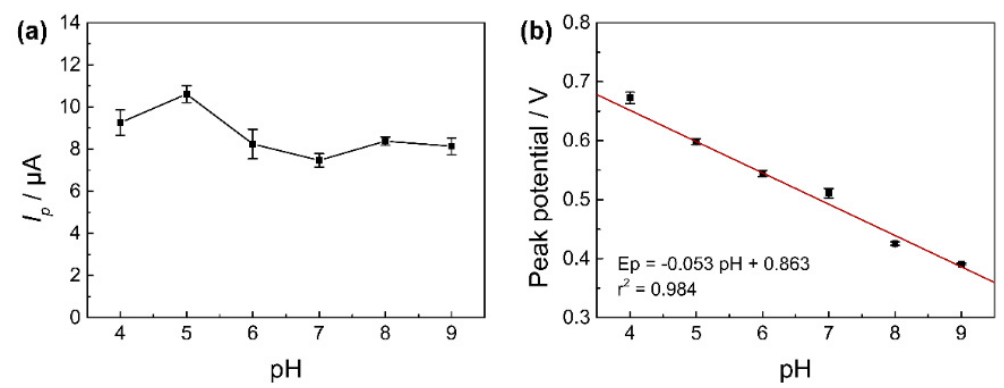

Figure 6. (a) Effect of $\mathrm{pH}$ on $I_{p}$ in $\mathrm{CV}$. (b) Plot of peak potential (Ep) to $\mathrm{pH}$ values. $\mathrm{CV}$ method: $100 \mu \mathrm{mol} \mathrm{L}-1$ of CBD in $10 \mathrm{mmol} \mathrm{L}^{-1}$ of PBs (pH 5.0, containing $10 \%$ methanol). Potential range of $0-0.8 \mathrm{~V}$. Scan rate of $0.05 \mathrm{~V} \mathrm{~s}^{-1}$.

\subsection{The Influence of the Scan Rate}

As an important parameter reflecting the performance of the electrode, the effect of different scan rates (from $5 \mathrm{mV} \mathrm{s}^{-1}$ to $200 \mathrm{mV} \mathrm{s}^{-1}$ ) on the electrochemical response of CBD in PBs (10 mmol L $\left.{ }^{-1}, \mathrm{pH} 7.0\right)$ was evaluated on the $\mathrm{Fe}_{3} \mathrm{O}_{4}-\mathrm{NH}_{2}$-GN/GCE, using the $\mathrm{CV}$ method. Figure 7a shows the resulting $\mathrm{CV}$ curves at a variety of scan rates. It can be seen that the peak currents increased and shifted with the increasing scan rates. A good linear relationship could be obtained between scan rate and peak current, which could be expressed as: $I_{p}=164.84 v+1.73\left(r^{2}=0.998\right)$ (Figure $\left.7 b\right)$, indicating that the oxidation of CBD was an adsorption-controlled process [41]. However, when the scan rate was increased to more than $200 \mathrm{mV} \mathrm{s}^{-1}\left(250 \mathrm{mV} \mathrm{s}^{-1}\right.$ and $\left.300 \mathrm{mV} \mathrm{s}^{-1}\right)$, the response did not grow proportionately to the former linear trend (lower than former trend). Another linear dependence of the logarithm of the peak current $\left(\log I_{p}\right)$ against the logarithm of the scan rate could also be observed, which was fitted as: $\log I_{\mathrm{p}}=0.735 \log v+2.00\left(r^{2}=0.982\right)$ (Figure 7c). This trend suggests that the electrochemical reaction was controlled by both diffusion and adsorption [42].
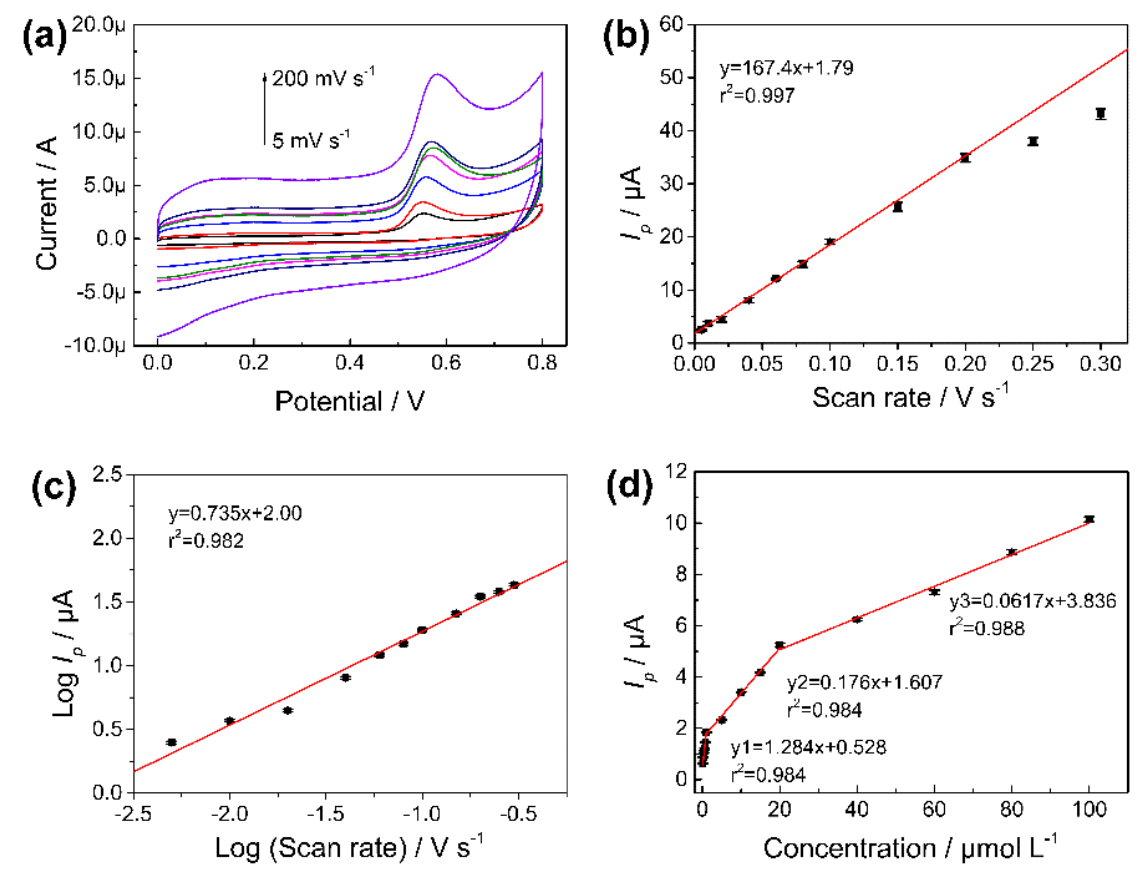

Figure 7. (a) $\mathrm{CV}$ of $\mathrm{Fe}_{3} \mathrm{O}_{4}-\mathrm{NH}_{2}-\mathrm{GN} / \mathrm{GCE}$ in CBD solution at different scan rates. (b) The linear graph of $I_{p}$ and scan rates. (c) The linear graph of $\log I_{p}$ and $\log$ (scan rate). (d) Plot of $I_{p}$ versus concentration of CBD. CV method: $100 \mu \mathrm{mol} \mathrm{L}^{-1}$ of CBD in $10 \mathrm{mmol} \mathrm{L}^{-1}$ of PBs (pH 5.0, containing $10 \%$ methanol). Potential range of $0-0.8 \mathrm{~V}$. Scan rate of $0.05 \mathrm{~V} \mathrm{~s}^{-1}$. 


\subsection{Quantitative Analysis of $C B D$}

In order to study the quantitative analysis ability of the fabricated $\mathrm{Fe}_{3} \mathrm{O}_{4}-\mathrm{NH}_{2}-\mathrm{GN} / \mathrm{GCE}$, the $C V$ curves of $C B D$ at different concentrations from $0.1 \mu \mathrm{mol} \mathrm{L}^{-1}$ to $100 \mu \mathrm{mol} \mathrm{L}{ }^{-1}$ were observed in PBs ( $0.01 \mathrm{~mol} / \mathrm{L}, \mathrm{pH} 5.0)$. The results illustrated that the peak current increased with increasing $\mathrm{CBD}$ concentrations, and three sections of linear dependences could be found between the peak current and the $\mathrm{CBD}$ concentration during this range, with a detection limit of $0.04 \mu \mathrm{mol} \mathrm{L}{ }^{-1}(S / N=3)$, which is consistent with Liu's work [43]. The plot of peak current versus CBD concentration is shown in Figure $7 \mathrm{~d}$. The three regression equations could be respectively expressed as: $I_{p 1}=1.284 \mathrm{C}_{1}+0.528\left(0.1-0.974 \mu \mathrm{mol} \mathrm{L}^{-1}\right.$, $\left.r^{2}=0.984\right), I_{p 2}=0.176 \mathrm{C}_{2}+1.607\left(0.974-19.494 \mu \mathrm{mol} \mathrm{L}-1, r^{2}=0.984\right)$, and $I_{p 3}=0.0617 \mathrm{C}_{3}+$ $3.836\left(19.494-100 \mu \mathrm{mol} \mathrm{L}^{-1}, r^{2}=0.988\right)$. It could be found in three regression equations that the slope of the peak current at low concentration was higher than at high concentration. At a lower analyte concentration, the number of active sites on the electrode was relatively higher. However, because of the occupancy of-and decrease in the number of-active sites at higher analyte concentrations, the sensitivity and the slope became lower [44]. This demonstrates that the quantitative analysis of CBD using the $\mathrm{Fe}_{3} \mathrm{O}_{4}-\mathrm{NH}_{2}-\mathrm{GN} / \mathrm{GCE}$ was interesting and acceptable [45]. The detection abilities of the reported electrochemical sensors for CBD are listed and compared with the $\mathrm{Fe}_{3} \mathrm{O}_{4}-\mathrm{NH}_{2}$-GN/GCE in Table 2. Through the comparison, the proposed $\mathrm{Fe}_{3} \mathrm{O}_{4}-\mathrm{NH}_{2}-\mathrm{GN} / \mathrm{GCE}$ exhibited a competitive detection capability and sensitivity for CBD.

Table 2. Comparison of different reported sensors for the electrochemical determination of CBD.

\begin{tabular}{cccc}
\hline Electrode & Linear Rage $\left(\boldsymbol{\mu m o l ~ L} \mathbf{~ L}^{-\mathbf{1}}\right)$ & LOD $\left(\boldsymbol{\mu m o l ~ L} \mathbf{~ L}^{-\mathbf{1}}\right)$ & Ref. \\
\hline GC/CB & $0.96-6.37$ & 0.35 & {$[39]$} \\
Sonogel-Carbon-PEDOT & $1.59-19.1$ & 0.94 & {$[34]$} \\
NACE-ED & $0.32-31.8$ & 0.064 & {$[46]$} \\
GCE & $-\mathrm{NM}$ & $-\mathrm{NM}$ & {$[47]$} \\
$\mathrm{Fe}_{3} \mathrm{O}_{4}-\mathrm{NH}_{2}$-GN/GCE & $0.1-100.0$ & 0.04 & This study \\
\hline
\end{tabular}

GC/CB: glassy carbon/carbon black; PEDOT: poly-(3,4-ethylenedioxythiophene); NACE-ED: non-aqueous capillary electrophoresis-electrochemical detection; NM. Not mentioned.

\subsection{Practicability of the $\mathrm{Fe}_{3} \mathrm{O}_{4}-\mathrm{NH}_{2}-\mathrm{GN} / \mathrm{GCE}$}

The anti-interference ability, repeatability, and stability of the $\mathrm{Fe}_{3} \mathrm{O}_{4}-\mathrm{NH}_{2}-\mathrm{GN} / \mathrm{GCE}$ were tested, and the results were satisfactory (see the ESM). Moreover, the detection ability of the $\mathrm{Fe}_{3} \mathrm{O}_{4}-\mathrm{NH}_{2}$-GN/GCE for CBD was evaluated in the extract of $C$. sativa leaves. In order to verify the results, the standard addition method was employed by spiking different amounts of CBD into samples. The results are shown in Table 3 and compared with those obtained via the HPLC method. The recoveries ranged from $99.1 \%$ to $100.4 \%$, indicating that the determination was reliable, and there was consistency between the concentrations of CBD measured by both electrochemical and HPLC methods.

Table 3. Determination of CBD in real samples. $(n=3)$.

\begin{tabular}{cccccc}
\hline Samples & Added $\left(\mu \mathrm{mol} \mathrm{L}^{-\mathbf{1}}\right)$ & Found $\left(\mu \mathrm{mol} \mathrm{L}^{-\mathbf{1}}\right)$ & Recovery $(\%)$ & RSD $(\%)$ & HPLC $\left.^{(\mu \mathrm{mol} \mathrm{L}} \mathbf{~}^{-\mathbf{1}}\right)$ \\
\hline \multirow{3}{*}{ Extract of C. sativa } & 0 & 11.95 & - & 2.23 & 12.06 \\
& 1.0 & 13.00 & 100.4 & 2.05 & - \\
\hline
\end{tabular}

\section{Conclusions}

In this study, an electrochemical sensor $\left(\mathrm{Fe}_{3} \mathrm{O}_{4}-\mathrm{NH}_{2}\right.$-GN/GCE) was fabricated for the detection of CBD. The applied materials and fabrication conditions were compared and optimized via various characterizations and evaluations. The performance of the $\mathrm{Fe}_{3} \mathrm{O}_{4^{-}}$ $\mathrm{NH}_{2}-\mathrm{GN} / \mathrm{GCE}$ was investigated for aspects including $\mathrm{pH}$, scan rate, anti-interference 
ability, repeatability, and stability. As a result, the proposed $\mathrm{Fe}_{3} \mathrm{O}_{4}-\mathrm{NH}_{2}-\mathrm{GN} / \mathrm{GCE}$ showed an improved electrochemical response compared to a bare GCE. It displayed quantitative analysis ability for CBD, with a linear range of $0.1 \mu \mathrm{mol} \mathrm{L}-1$ to $100 \mu \mathrm{mol} \mathrm{L} \mathrm{L}^{-1}$. The practicability test also showed that the result was in good agreement with that of the HPLC method in the detection of CBD in real samples. Based on these findings, the $\mathrm{Fe}_{3} \mathrm{O}_{4}-\mathrm{NH}_{2}-\mathrm{GN} / \mathrm{GCE}$ could be further utilized for the detection of active compounds in natural extracts.

Supplementary Materials: The following are available online at https://www.mdpi.com/article/10 $.3390 /$ nano11092227/s1, Figure S1: (a) $I_{p}$ ratios of $\mathrm{Fe}_{3} \mathrm{O}_{4}-\mathrm{NH}_{2}-\mathrm{GN} / \mathrm{GCE}$ in CBD solution containing various interfering substances. CV method: $100 \mu \mathrm{mol} \mathrm{L}^{-1}$ of CBD in $10 \mathrm{mmol} \mathrm{L}^{-1}$ of PBs (pH 5.0, containing $10 \%$ methanol). Potential range at $0-0.8 \mathrm{~V}$. Scan rate at $0.05 \mathrm{~V} \mathrm{~s}^{-1}$, Figure S2: Repeatability of $\mathrm{Fe}_{3} \mathrm{O}_{4}-\mathrm{NH}_{2}-\mathrm{GN} / \mathrm{GCE}$ in CBD solution. CV method: $100 \mu \mathrm{mol} \mathrm{L}{ }^{-1}$ of CBD in $10 \mathrm{mmol} \mathrm{L}^{-1}$ of $\mathrm{PBs}$ (pH 5.0, containing 10\% methanol). Potential range at $0-0.8 \mathrm{~V}$. Scan rate at $0.05 \mathrm{~V} \mathrm{~s}^{-1}$, Figure S3: Stability of $\mathrm{Fe}_{3} \mathrm{O}_{4}-\mathrm{NH}_{2}$-GN/GCE in CBD solution. CV method: $100 \mu \mathrm{mol} \mathrm{L}-1$ of CBD in $10 \mathrm{mmol} \mathrm{L}^{-1}$ of PBs (pH 5.0, containing 10\% methanol). Potential range at $0-0.8 \mathrm{~V}$. Scan rate at $0.05 \mathrm{~V} \mathrm{~s}^{-1}$.

Author Contributions: Conceptualization, L.L.; data curation, Y.Z.; formal analysis, Z.Y. and C.H.; methodology, A.X. All authors have read and agreed to the published version of the manuscript.

Funding: This research received no external funding.

Institutional Review Board Statement: Not applicable.

Informed Consent Statement: Not applicable.

Data Availability Statement: The data presented in this study are available on request from the corresponding author.

Acknowledgments: This work was supported by the National Agricultural Science and Technology Innovation Project.

Conflicts of Interest: The authors declare no conflict of interest.

\section{References}

1. Alegre-Zurano, L.; Martín-Sánchez, A.; Valverde, O. Behavioural and molecular effects of cannabidiolic acid in mice. Life Sci. 2020, 259, 118271. [CrossRef] [PubMed]

2. Bonini, S.A.; Premoli, M.; Tambaro, S.; Kumar, A.; Maccarinelli, G.; Memo, M.; Mastinu, A. Cannabis sativa: A comprehensive ethnopharmacological review of a medicinal plant with a long history. J. Ethnopharmacol. 2018, 227, 300-315. [CrossRef]

3. Shannon, S.; Lewis, N.; Lee, H.; Hughes, S. Cannabidiol in Anxiety and Sleep: A Large Case Series. Perm. J. 2019, 23, 18-41. [CrossRef] [PubMed]

4. Di Marco Pisciottano, I.; Guadagnuolo, G.; Soprano, V.; De Crescenzo, M.; Gallo, P. A rapid method to determine nine natural cannabinoids in beverages and food derived from Cannabis sativa by liquid chromatography coupled to tandem mass spectrometry on a QTRAP 4000. Rapid Commun. Mass Spectrom. 2018, 32, 1728-1736. [CrossRef] [PubMed]

5. Crescente, G.; Piccolella, S.; Esposito, A.; Scognamiglio, M.; Fiorentino, A.; Pacifico, S. Chemical composition and nutraceutical properties of hempseed: An ancient food with actual functional value. Phytochem. Rev. 2018, 17, 733-749. [CrossRef]

6. McRae, G.; Melanson, J.E. Quantitative determination and validation of 17 cannabinoids in cannabis and hemp using liquid chromatography-tandem mass spectrometry. Anal. Bioanal. Chem. 2020, 412, 7381-7393. [CrossRef]

7. Nemeškalová, A.; Hájková, K.; Mikulů, L.; Sýkora, D.; Kuchař, M. Combination of UV and MS/MS detection for the LC analysis of cannabidiol-rich products. Talanta 2020, 219, 121250. [CrossRef]

8. Shokoohi Rad, S.; Dalali, N.; Baheri, T. Combination of magnetic solid-phase extraction with dispersive liquid-liquid microextraction followed by GC-MS for trace analysis of synthetic cannabinoids in plasma samples. Micro Nano Lett. 2020, 15, 545-549. [CrossRef]

9. Wanklyn, C.; Burton, D.; Enston, E.; Bartlett, C.-A.; Taylor, S.; Raniczkowska, A.; Black, M.; Murphy, L. Disposable screen printed sensor for the electrochemical detection of delta-9-tetrahydrocannabinol in undiluted saliva. Chem. Cent. J. 2016, 10, 1. [CrossRef]

10. How, Z.T.; El-Din, M.G. A critical review on the detection, occurrence, fate, toxicity, and removal of cannabinoids in the water system and the environment. Environ. Pollut. 2021, 268. [CrossRef]

11. Wei, K.; Sun, J.; Gao, Q.; Yang, X.; Ye, Y.; Ji, J.; Sun, X. 3D “honeycomb” cell/carbon nanofiber/gelatin methacryloyl (GelMA) modified screen-printed electrode for electrochemical assessment of the combined toxicity of deoxynivalenol family mycotoxins. Bioelectrochemistry 2021, 139, 107743. [CrossRef] 
12. Raghavan, V.S.; O’Driscoll, B.; Bloor, J.M.; Li, B.; Katare, P.; Sethi, J.; Gorthi, S.S.; Jenkins, D. Emerging graphene-based sensors for the detection of food adulterants and toxicants-A review. Food Chem. 2021, 355, 129547. [CrossRef]

13. Maphiri, V.M.; Rutavi, G.; Sylla, N.F.; Adewinbi, S.A.; Fasakin, O.; Manyala, N. Novel Thermally Reduced Graphene Oxide Microsupercapacitor Fabricated via Mask—Free AxiDraw Direct Writing. Nanomaterials 2021, 11, 1909. [CrossRef]

14. Chen, S.-Y.; Chung, S.-H. Advanced Current Collectors with Carbon Nanofoams for Electrochemically Stable Lithium-Sulfur Cells. Nanomaterials 2021, 11, 2083. [CrossRef]

15. Bukkitgar, S.D.; Shetti, N.P.; Aminabhavi, T.M. Electrochemical investigations for COVID-19 detection-A comparison with other viral detection methods. Chem. Eng. J. 2021, 420, 127575. [CrossRef]

16. Sundaresan, R.; Mariyappan, V.; Chen, S.-M.; Keerthi, M.; Ramachandran, R. Electrochemical sensor for detection of tryptophan in the milk sample based on MnWO4 nanoplates encapsulated RGO nanocomposite. Colloids Surf. A 2021, 625, 126889. [CrossRef]

17. Nasrollahpour, H.; Isildak, I.; Rashidi, M.-R.; Hashemi, E.A.; Naseri, A.; Khalilzadeh, B. Ultrasensitive bioassaying of HER-2 protein for diagnosis of breast cancer using reduced graphene oxide/chitosan as nanobiocompatible platform. Cancer Nanotechnol. 2021, 12, 10. [CrossRef]

18. You, Z.; Fu, Y.; Xiao, A.; Liu, L.; Huang, S. Magnetic molecularly imprinting polymers and reduced graphene oxide modified electrochemical sensor for the selective and sensitive determination of luteolin in natural extract. Arab. J. Chem. 2021, 14, 102990. [CrossRef]

19. Carneiro, P.; Morais, S.; Pereira, M.C. Nanomaterials towards Biosensing of Alzheimer's Disease Biomarkers. Nanomaterials 2019, 9, 1663. [CrossRef] [PubMed]

20. Li, J.; Li, Y.; Zhai, X.; Cao, Y.; Zhao, J.; Tang, Y.; Han, K. Sensitive electrochemical detection of hepatitis C virus subtype based on nucleotides assisted magnetic reduced graphene oxide-copper nano-composite. Electrochem. Commun. 2020, 110, 106601. [CrossRef]

21. Chimezie, A.B.; Hajian, R.; Yusof, N.A.; Woi, P.M.; Shams, N. Fabrication of reduced graphene oxide-magnetic nanocomposite $\left(\mathrm{rGO}-\mathrm{Fe}_{3} \mathrm{O}_{4}\right)$ as an electrochemical sensor for trace determination of $\mathrm{As}(\mathrm{III})$ in water resources. J. Electroanal. Chem. 2017, 796, 33-42. [CrossRef]

22. Sun, B.; Gou, X.; Bai, R.; Abdelmoaty, A.A.A.; Ma, Y.; Zheng, X.; Hu, F. Direct electrochemistry and electrocatalysis of lobetyolin via magnetic functionalized reduced graphene oxide film fabricated electrochemical sensor. Mater. Sci. Eng. C 2017, 74, 515-524. [CrossRef] [PubMed]

23. Pakapongpan, S.; Poo-arporn, R.P. Self-assembly of glucose oxidase on reduced graphene oxide-magnetic nanoparticles nanocomposite-based direct electrochemistry for reagentless glucose biosensor. Mater. Sci. Eng. C 2017, 76, 398-405. [CrossRef]

24. Sharafeldin, M.; Bishop, G.W.; Bhakta, S.; El-Sawy, A.; Suib, S.L.; Rusling, J.F. $\mathrm{Fe}_{3} \mathrm{O}_{4}$ nanoparticles on graphene oxide sheets for isolation and ultrasensitive amperometric detection of cancer biomarker proteins. Biosens. Bioelectron. 2017, 91, 359-366. [CrossRef] [PubMed]

25. Mathew, G.; Dey, P.; Das, R.; Chowdhury, S.D.; Paul Das, M.; Veluswamy, P.; Neppolian, B.; Das, J. Direct electrochemical reduction of hematite decorated graphene oxide $\left(\alpha-\mathrm{Fe}_{2} \mathrm{O}_{3} @ e r G \mathrm{O}\right)$ nanocomposite for selective detection of Parkinson's disease biomarker. Biosens. Bioelectron. 2018, 115, 53-60. [CrossRef]

26. Liu, Y.; Huang, Y.; Xiao, A.; Qiu, H.; Liu, L. Preparation of Magnetic Fe3O4/MIL-88A Nanocomposite and Its Adsorption Properties for Bromophenol Blue Dye in Aqueous Solution. Nanomaterials 2019, 9, 51. [CrossRef]

27. Chen, J.; Leng, J.; Yang, X.A.; Liao, L.P.; Liu, L.L.; Xiao, A.P. Enhanced Performance of Magnetic Graphene Oxide-Immobilized Laccase and Its Application for the Decolorization of Dyes. Molecules 2017, 22, 221. [CrossRef]

28. Poo-arporn, Y.; Pakapongpan, S.; Chanlek, N.; Poo-arporn, R.P. The development of disposable electrochemical sensor based on $\mathrm{Fe}_{3} \mathrm{O}_{4}$-doped reduced graphene oxide modified magnetic screen-printed electrode for ractopamine determination in pork sample. Sens. Actuators B 2019, 284, 164-171. [CrossRef]

29. Cen, Y.; Xiao, A.P.; Chen, X.Q.; Liu, L.L. Screening and separation of alpha-amylase inhibitors from Solanum nigrum with amylase-functionalized magnetic graphene oxide combined with high-speed counter-current chromatography. J. Sep. Sci. 2017, 40, 4780-4787. [CrossRef]

30. Liu, L.L.; Ma, Y.J.; Chen, X.Q.; Xiong, X.; Shi, S.Y. Screening and identification of BSA bound ligands from Puerariae lobata flower by BSA functionalized $\mathrm{Fe}_{3} \mathrm{O}_{4}$ magnetic nanoparticles coupled with HPLC-MS/MS. J. Chromatogr. B-Anal. Technol. Biomed. Life Sci. 2012, 887, 55-60. [CrossRef]

31. Kulkarni, S.B.; Patil, U.M.; Shackery, I.; Sohn, J.S.; Lee, S.; Park, B.; Jun, S. High-performance supercapacitor electrode based on a polyaniline nanofibers/3D graphene framework as an efficient charge transporter. J. Mater. Chem. A 2014, 2, 4989-4998. [CrossRef]

32. Wang, Q.; Gu, C.; Fu, Y.; Liu, L.; Xie, Y. Ultrasensitive Electrochemical Sensor for Luteolin Based on Zirconium MetalOrganic Framework UiO-66/Reduced Graphene Oxide Composite Modified Glass Carbon Electrode. Molecules 2020, 25, 4557. [CrossRef] [PubMed]

33. Xu, L.; Li, J.; Zhang, J.; Sun, J.; Gan, T.; Liu, Y. A disposable molecularly imprinted electrochemical sensor for the ultra-trace detection of the organophosphorus insecticide phosalone employing monodisperse Pt-doped UiO-66 for signal amplification. Analyst 2020, 145, 3245-3256. [CrossRef]

34. López-Iglesias, D.; García-Guzmán, J.J.; Zanardi, C.; Palacios-Santander, J.M.; Cubillana-Aguilera, L.; Pigani, L. Fast electroanalytical determination of Cannabidiol and Cannabinol in aqueous solution using Sonogel-Carbon-PEDOT devices. J. Electroanal. Chem. 2020, 878, 114591. [CrossRef] 
35. Renaud-Young, M.; Mayall, R.M.; Salehi, V.; Goledzinowski, M.; Comeau, F.J.E.; MacCallum, J.L.; Birss, V.I. Development of an ultra-sensitive electrochemical sensor for $\Delta$ 9-tetrahydrocannabinol (THC) and its metabolites using carbon paper electrodes. Electrochim. Acta 2019, 307, 351-359. [CrossRef]

36. Teymourian, H.; Salimi, A.; Khezrian, $\mathrm{S} . \mathrm{Fe}_{3} \mathrm{O}_{4}$ magnetic nanoparticles/reduced graphene oxide nanosheets as a novel electrochemical and bioeletrochemical sensing platform. Biosens. Bioelectron. 2013, 49, 1-8. [CrossRef] [PubMed]

37. Su, C.-W.; Tian, J.-H.; Ye, J.-J.; Chang, H.-W.; Tsai, Y.-C. Construction of a Label-Free Electrochemical Immunosensor Based on Zn-Co-S/Graphene Nanocomposites for Carbohydrate Antigen 19-9 Detection. Nanomaterials 2021, 11, 1475. [CrossRef]

38. Fu, Y.; You, Z.; Xiao, A.; Liu, L. Magnetic molecularly imprinting polymers, reduced graphene oxide, and zeolitic imidazolate frameworks modified electrochemical sensor for the selective and sensitive detection of catechin. Microchim. Acta 2021, 188, 71. [CrossRef] [PubMed]

39. Cirrincione, M.; Zanfrognini, B.; Pigani, L.; Protti, M.; Mercolini, L.; Zanardi, C. Development of an electrochemical sensor based on carbon black for the detection of cannabidiol in vegetable extracts. Analyst 2021, 146, 612-619. [CrossRef] [PubMed]

40. Šafranko, S.; Stanković, A.; Asserghine, A.; Jakovljević, M.; Hajra, S.; Nundy, S.; Medvidović-Kosanović, M.; Jokić, S. Electroactivated Disposable Pencil Graphite Electrode-New, Cost-effective, and Sensitive Electrochemical Detection of Bioflavonoid Hesperidin. Electroanalysis 2021, 33, 1063-1071. [CrossRef]

41. Zhang, J.; Zhang, X. Electrode material fabricated by loading cerium oxide nanoparticles on reduced graphene oxide and its application in electrochemical sensor for tryptophan. J. Alloys Compd. 2020, 842, 155934. [CrossRef]

42. Pierini, G.D.; Maccio, S.A.; Robledo, S.N.; Ferrari, A.G.-M.; Banks, C.E.; Fernández, H.; Zon, M.A. Screen-printed electrochemicalbased sensor for taxifolin determination in edible peanut oils. Microchem. J. 2020, 159, 105442. [CrossRef]

43. Liu, J.; Sun, L.; Li, G.; Hu, J.; He, Q. Ultrasensitive detection of dopamine via electrochemical route on spindle-like $\alpha$-Fe ${ }_{2} \mathrm{O}_{3}$ Mesocrystals/rGO modified GCE. Mater. Res. Bull. 2021, 133, 111050. [CrossRef]

44. Ganesh, H.V.S.; Patel, B.R.; Fini, H.; Chow, A.M.; Kerman, K. Electrochemical Detection of Gallic Acid-Capped Gold Nanoparticles Using a Multiwalled Carbon Nanotube-Reduced Graphene Oxide Nanocomposite Electrode. Anal. Chem. 2019, 91, 10116-10124. [CrossRef]

45. Wang, T.; Wang, C.; Xu, X.; Li, Z.; Li, D. One-Step Electrodeposition Synthesized Aunps/Mxene/ERGO for Selectivity Nitrite Sensing. Nanomaterials 2021, 11, 1892. [CrossRef]

46. Backofen, U.; Matysik, F.-M.; Lunte, C.E. Determination of cannabinoids in hair using high-pH $*$ non-aqueous electrolytes and electrochemical detection: Some aspects of sensitivity and selectivity. J. Chromatogr. A 2002, 942, 259-269. [CrossRef]

47. Hacke, A.C.M.; Lima, D.; de Costa, F.; Deshmukh, K.; Li, N.; Chow, A.M.; Marques, J.A.; Pereira, R.P.; Kerman, K. Probing the antioxidant activity of $\Delta$ 9-tetrahydrocannabinol and cannabidiol in Cannabis sativa extracts. Analyst 2019, 144, 4952-4961. [CrossRef] 